\title{
WHAT IS SUSTAINABLE DESIGN ENGINEERING (SDE)? PERSPECTIVES FROM A PROBLEM-BASED LEARNING EDUCATION: M.SC. IN SDE AT AALBORG UNIVERSITY COPENHAGEN
}

\author{
A. F. Valderrama Pineda and M. Niero ${ }^{凶}$ \\ Aalborg University Copenhagen, Denmark \\ $\triangle$ monian@plan.aau.dk
}

\begin{abstract}
Sustainable Design Engineering (SDE) is an emerging research field and the development of programmes aiming at educating sustainable design engineers is very limited. One example is the SDE program at the Aalborg University in Copenhagen, which is based on a Problem Based Learning (PBL) model. In this article we aim to address the following three research questions: i) why Sustainable Design Engineering? ii) what is Sustainable Design Engineering? iii) How can Sustainable Design Engineering be implemented? By means of two examples from master thesis projects in the building and food sectors.
\end{abstract}

Keywords: design education, sustainable design, engineering design, problem-based learning, science and technology studies

\section{Introduction}

The characteristics of traditional learning are content, lecturer and student, which in a Problem Based Learning (PBL) are substituted by problem, coach and problem solver, respectively. Key characteristics of PBL are (Kolmos et al., 2008):

- Activity-based learning, which is a central part of the PBL learning process, requiring activities involving research methods, decision-making, planning and writing;

- Inter-disciplinary learning, related to problem orientation and participant-directed processes, so solution of the problem can extend beyond traditional subject-related boundaries and methods;

- Group-based learning, since the majority of the learning process takes place in groups or teams. Personal competencies are thereby developed, so that students learn to handle the process of group co-operation in all its stages.

Since its inception in the 1980s, PBL has developed in diverse ways worldwide, with relatively little mapping of its theories, practice, or disciplinary differences. PBL is an approach to learning that is affected by the structural and pedagogical environment into which it is placed (that is, the discipline or subject, the instructors, and the organization) (Savin-Badin, 2014).

The discipline where PBL has been mainly adopted is medical study, but there are many examples of educational programmes based on PBL in the Design field, less in the more traditional Engineering field (Kolmos et al., 2008). Sustainable Design Engineering (SDE) is an emerging research field and the development of programmes aiming at educating sustainable design engineers is very limited 
(Mulder, 2019). One example is the Bachelor and Master Programme in SDE at the Aalborg University in Copenhagen (AAU-CPH). The focus of this article is on the Master programme, meanwhile for a description of the Bachelor programme see Pineda and Jørgensen (2018).

In the present article we aim to discuss the following three research questions: i) why Sustainable Design Engineering? ii) what is Sustainable Design Engineering? iii) How can Sustainable Design Engineering be implemented?

We will first briefly describe what the AAU-PBL model is (section 1.1), then we will explain why Sustainable Design Engineering is needed and the limitation of traditional disciplinary approaches (section 2). In section 3 we will describe how SDE is implemented in the master programme in SDE at AAU-CPH and finally in section 4 we will illustrate how SDE can be implemented in practice, drawing on two examples from recent master thesis projects successfully defended at AAU-CPH during the 2019 spring semester, in the building (section 4.1) and food (section 4.2) sectors, respectively. A short conclusion is then presented (section 5).

\subsection{Problem based learning at Aalborg University (AAU-PBL model)}

"All educational activities at Aalborg University involve Problem-Based project
work, which takes as its point of departure a set of principles that constitute the
Aalborg model of Problem-Based Learning (PBL)." (Askehave et al., 2015, p. 3)

In the Aalborg model of PBL (hereafter, AAU-PBL model) the assumption is that students learn best when applying theory and research based knowledge in their work with an authentic problem. At the same time, in the AAU-PBL model, which is based on 6 principles described in Table 1, students are supported in the development of their communication and cooperation competences, and in acquiring the skills required when taking an analytical and result-oriented approach (Askehave et al., 2015).

Table 1. List and description of the 6 principles of Aalborg University problem based learning model (AAU-PBL model) (Askehave et al., 2015)

\begin{tabular}{|c|c|c|}
\hline $\begin{array}{l}\text { Principle } \\
\mathrm{n} \text {. }\end{array}$ & Name & Description \\
\hline 1 & $\begin{array}{l}\text { The problem } \\
\text { as point of } \\
\text { departure }\end{array}$ & $\begin{array}{l}\text { A problem can be both theoretical and practical. It must also be authentic (i.e. of } \\
\text { relevance outside of academia) and scientifically based (i.e. comprehensible, can be } \\
\text { analysed and solved, taking an interdisciplinary approach) }\end{array}$ \\
\hline 2 & $\begin{array}{l}\text { Projects } \\
\text { organized in } \\
\text { groups }\end{array}$ & $\begin{array}{l}\text { A project represents a time-limited and targeted process in which a problem may be } \\
\text { phrased, analysed and solved, resulting in a tangible product, e.g. a project report. The } \\
\text { target of the project is determined in the problem formulation, which will be developed } \\
\text { continually during the course of the project, like the project methods. }\end{array}$ \\
\hline 3 & $\begin{array}{l}\text { The project is } \\
\text { supported by } \\
\text { courses }\end{array}$ & $\begin{array}{l}\text { In order to ensure that students become familiar with a wide range of theories and } \\
\text { methods which they can use in their project work, they will participate in both } \\
\text { obligatory and optional courses, which include different student activities, e.g. lectures, } \\
\text { workshops, seminars and exercises. }\end{array}$ \\
\hline 4 & $\begin{array}{l}\text { Collaboration: } \\
\text { groups, } \\
\text { supervisor, } \\
\text { external } \\
\text { partners }\end{array}$ & $\begin{array}{l}\text { A group of students work closely together in managing and completing a project over } \\
\text { an extended period of time, taking a problem as the point of departure for their work. } \\
\text { The group work includes aspects such as knowledge sharing, collective decision- } \\
\text { making, academic discussions, action coordination and mutual critical feedback. } \\
\text { Student groups also engage in close cooperation with their supervisor(s) and with } \\
\text { external partners, e.g. businesses. }\end{array}$ \\
\hline 5 & Exemplarity & $\begin{array}{l}\text { The curriculum framework, supported by the supervisor, aims at ensuring that students' } \\
\text { project work is exemplary as regards both content and approach. Exemplarity implies } \\
\text { that learning outcomes achieved during concrete project work are transferable to similar } \\
\text { situations encountered by students in their professional careers. }\end{array}$ \\
\hline 6 & $\begin{array}{l}\text { Student } \\
\text { responsibility } \\
\text { for learning }\end{array}$ & $\begin{array}{l}\text { Within the framework and objectives of the curriculum, the students are largely free to } \\
\text { choose the content of their own projects, and thus to determine key elements of their } \\
\text { study programme. At the same time, students are responsible for a considerable part of } \\
\text { their own ongoing academic self-reflection. The group is supported by one or more } \\
\text { supervisors serving to ensure that the work undertaken by the group meets the } \\
\text { requirements stipulated in the curriculum. }\end{array}$ \\
\hline
\end{tabular}




\section{Why sustainable design engineering?}

Sustainable Design Engineering is a combination of three existing knowledge areas that have different traditions. Knowledge on sustainability can be traced way back for centuries. However, the focus on working definitions and applicable methods to assess and give direction to sustainable solutions starts formally with the Brundtland report in 1987 (Brundtland et al., 1987). Since then the discussion has been intense at the level of fundamental definitions (Kuhlman and Farrington, 2010), and focus areas with some robust approaches to physical aspects (Rockström et al., 2009) and others to social aspects (Leach et al., 2013). Zooming out it is necessary to acknowledge that we are in the middle ages of sustainability, still caught in the old modern paradigm of resource exploitation and economic growth at all costs, and that in this context, a serious systematic approach to a reorganization of global society in a way in which sustainability is achieved is still not clear, as clearly reflected in the disparate and unsystematic presentation of the Sustainable Development Goals and the different strategies to achieve them (Randers et al., 2018). Therefore, rather than adopting a working definition or a specific approach to sustainability, the teachers of the program acknowledge that there is a knowledge development in the making in terms of what sustainability is in specific projects.

Industrial Design and Design Engineering have traditionally been disciplines committed to the creation of new products. Since the advent of green design and eco-design, the field has expanded to engulf product service systems, social innovation, and transition design. However, the majority of projects and research efforts are still focused on product and physical components of existing systems. This focus alone has limited potential. However it is important to acknowledge that this focus renders the bulk of research and knowledge production on sustainable design of products and physical components limited. Those design projects and approaches that assume the challenge of supporting radical systemic changes to the main sociotechnical systems in societies have a higher transformative potential, but currently are the ones that deserve less attention in research in design and engineering design communities (Ceschin and Gaziulusoy, 2016; Pineda and Jørgensen, 2018).

Finally engineering has traditionally been a huge array of subdisciplines, each concentrated in specific technical challenges of existing and emerging technological systems. This has make engineering knowledge fragmented and tightly coupled to existing systems. A side effect of this substantial feature of the profession and the way engineers are educated discourages radical innovation. Therefore it is naïve to think that existing engineering knowledge can be used to achieve sustainability. A more honest approach, the one we adopt in the program, is that existing engineering knowledge has to be evaluated and either improved or radically changed to support projects and developments towards sustainability (Dym et al., 2005).

The field of Science and Technology Studies (STS) has produced a number of conceptual approaches that support the critical analysis of existing knowledge in science, technology and social sciences; identify ways of improving them for a given purpose; and supporting the adaptation and development of tools and methods that can support the staging and development of radical transformative processes towards sustainability (Clausen and Yosinaka, 2007; Storni, 2015; Pineda and Jørgensen, 2018).

Figure 1 shows schematically the areas that need to be integrated in Sustainable Design Engineering. Sustainability needs to transcend the unsystematic approaches reflected most recently in the disparate Sustainable Development Goals (SDGs) approach. Design requires the further development of initiatives that transcend product design and assume a systemic and transitions perspective. Engineering needs also to transcend the current fragmentation into technical systems whose optimization is not going to deliver on sustainability. The approach we offer uses the theoretical body of Science and Technology Studies as the integrative backbone because they allow to analyse knowledge and technologies as collective creations that can be improved. 


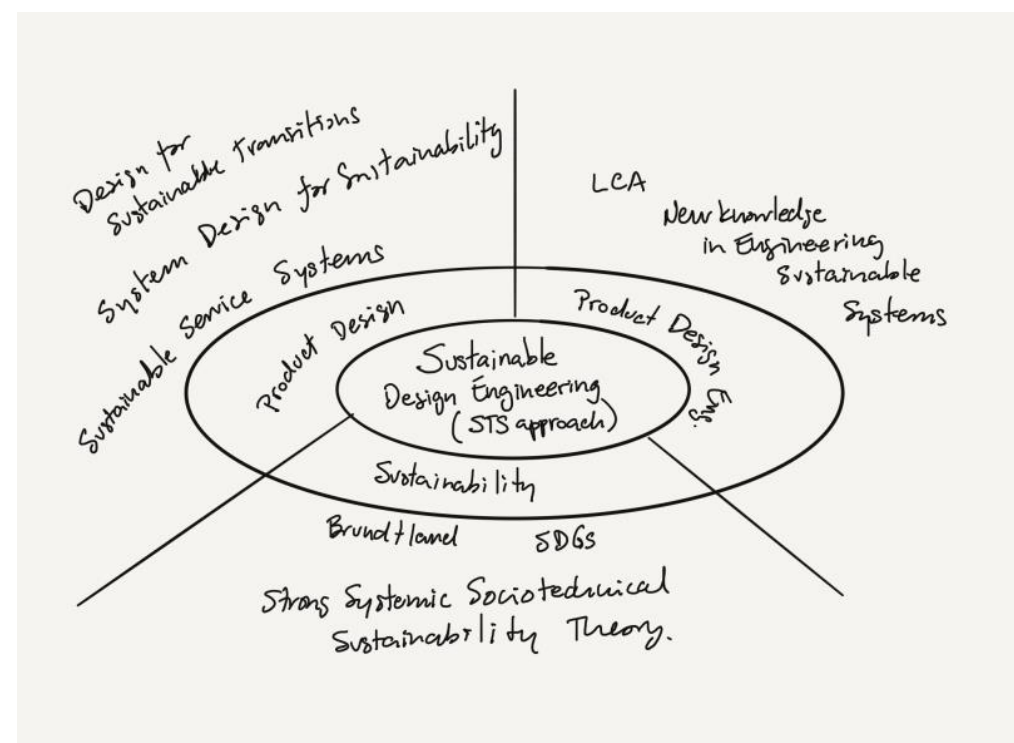

Figure 1. Sustainable design engineering (SDE) discipline sketch.

\section{What is SDE at Aalborg University Copenhagen?}

The Master's programme in Sustainable Design is a 2 year full time engineering education with special emphasis on design and innovation of sustainable solutions. The programme includes interdisciplinary components to satisfy the need for combining methods from social science and technology studies with technical subjects and design practices. The programme aims at providing students with the ability to understand, stage and carry out innovative processes leading to design and the implementation of sustainable products, services and socio-material system solutions through involvement of relevant actors. The programme's focus on sustainability is reflecting the challenges that development, production, consumption and dismantling of technologies pose for resource utilisation and climate. It builds on the broad notion of sustainability including the environmental, the social and the economical aspect. The realisation of these societal goals implies a focus on sustainable transitions in a design perspective, which is a core activity in the programme. (https://www.en.aau.dk/ education/master/sustainable-design/academic-content/). This implies that traditional subjects of product design and engineering are not the focus of the program. The emphasis is on changing dynamics towards sustainability. An overview of the semester project themes and courses is in Figure 2. For each of the courses and project modules, learning outcomes, specified in terms of knowledge, skills and competences are defined.

\begin{tabular}{|c|c|c|c|c|c|c|}
\hline & 5 ECTS & 5 ECTS & 5 ECTS & 5 ECTS & 5 ECTS & 5 ECTS \\
\hline 1 & \multicolumn{3}{|c|}{ Staging Collaborative Design for Sustainability } & $\begin{array}{c}\text { Design in } \\
\text { Organizations }\end{array}$ & $\begin{array}{c}\text { Sustainable } \\
\text { Design and } \\
\text { Manufacturing }\end{array}$ & $\begin{array}{c}\text { Design for } \\
\text { Sustainability }\end{array}$ \\
\hline 2 & \multicolumn{3}{|c|}{ Design for Sustainbility Transitions } & $\begin{array}{l}\text { Sustainable } \\
\text { Transitions }\end{array}$ & $\begin{array}{l}\text { Market Creation } \\
\text { and } \\
\text { Entrepreneurship }\end{array}$ & $\begin{array}{c}\text { Concept Driven } \\
\text { Change }\end{array}$ \\
\hline 3 & \multicolumn{6}{|c|}{ 1. Design with a company or organization 2. Design with People 3. Design with a research group 4. Exchange } \\
\hline 4 & \multicolumn{6}{|c|}{ Master Thesis } \\
\hline
\end{tabular}

Figure 2. Academic content of the Master's programme in sustainable design at Aalborg University Copenhagen. 
During the first seminar held in February 2019 to kick off the 4th semester of the SDE program, we asked the students $(\mathrm{N}=29)$ to address what challenges and questions we are facing with regard to SDE. Their replies are exemplified in Figure 3 in terms of the most relevant questions to be addressed.

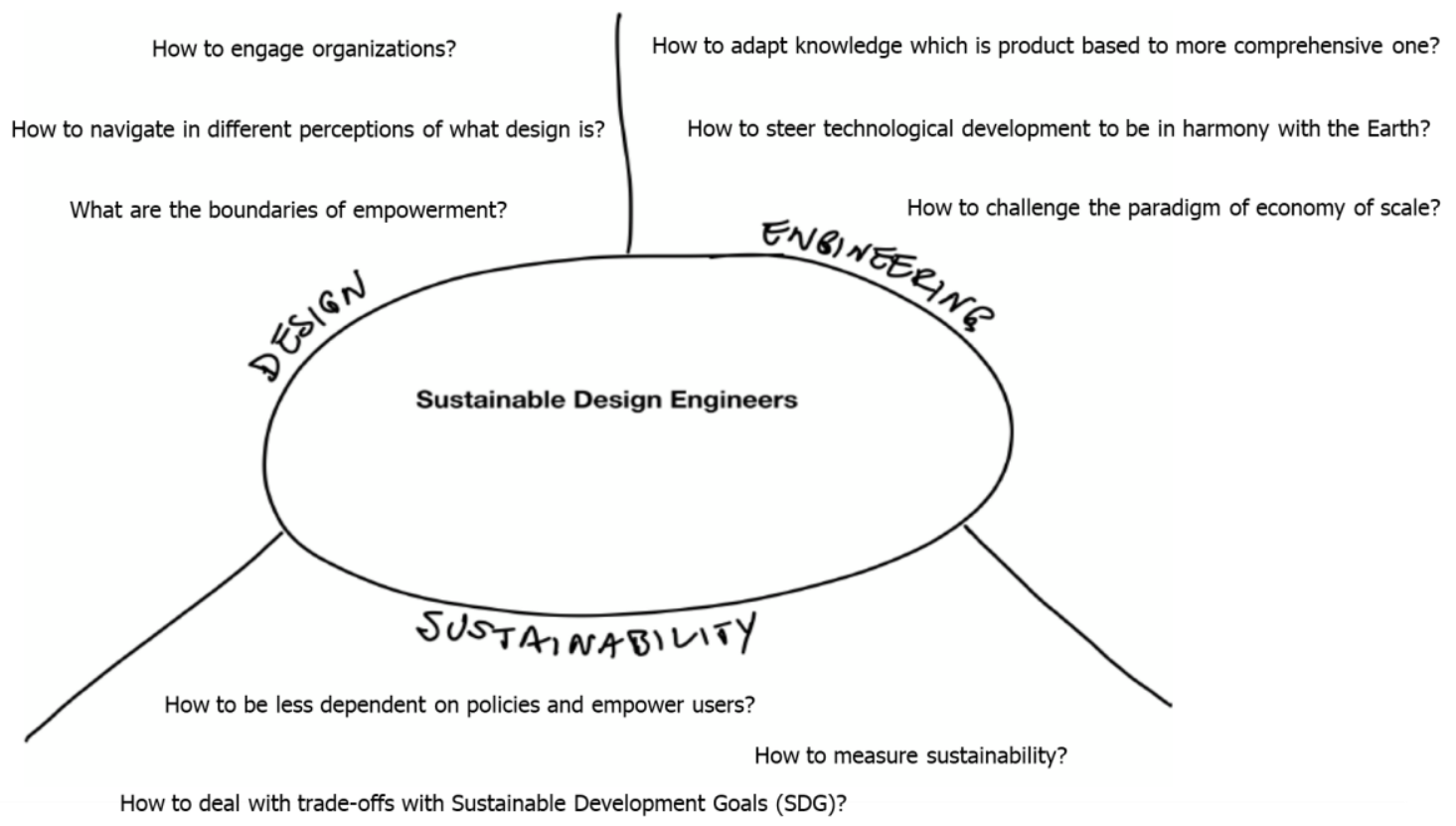

Figure 3. Categorization of most relevant questions to be addressed in relation to sustainable design engineering (SDE). Elaboration from students' feedback.

Most of the questions that have been discussed refer to the need of including a systematic approach while dealing with sustainability issues and that sectorial approaches and methods are limited in their ability to address long term sustainability challenges, so the status-quo needs to be challenged.

"Disciplines where fundamental questions are not asked, are dying"(Pineda A.V., Copenhagen, 8.2.2019)

\section{How can SDE be implemented? Examples from master theses at AAU-CPH}

In this section we present two examples of how SDE can be implemented in practice to illustrate the types of problems Sustainable Design Engineers focus on and how they approach them. We refer to two sectors where the implementation of the circular economy framework is relevant, namely the building sector and the food sector, being "construction and demolition" and "food waste" two of the priority sectors identified in the European Circular Economy Action Plan (EC, 2015).

\subsection{Building sector}

Two students decided to work with stakeholders in the building industry, who are interested in making the whole industry more sustainable (Cara D'anjo and Tolman, 2019). One strategy to achieve this is to create convenient and valuable connections with other industries in the country. The selected connection in this project was to the clothing industry. The initial challenge to approach was what to do with the current production of clothing waste in Denmark. Can there be a way to transform the many tons of textile waste that are currently incinerated every year to a resource for the building industry? What kind of products or services can such a re-purposing of a material feed into? Thus, they formulated the following research question (RQ): "How can the development of a building component made from post-consumer waste textiles act to initialise a gradual system reconfiguration in the socio-technical system that is the building sector?" 
The first part of the project consisted of conducting exploratory activities with stakeholders in order to determine what kind of uses different components made of recycled clothing waste could have. Many options were considered, e.g. acoustic panels, movable partitions, floor finishes and insulation. Through participatory workshops, the students and the stakeholders agreed to focus on insulation.

The main contribution of their project is both practical and conceptual. With inspiration from Sustainable Transitions literature the students framed the design of a possible new component as a contributor to a long term radical systemic change. This meant that the focus of the project could not be limited to a material substitution approach, which in fact is valuable in itself as the dominant material in insulation is not sustainable in Denmark. However, the students analysed the context of operation with a systemic approach, and considered that substituting insulation material would have limited scope. There was a need to consider inter-systemic relations to systems of indoor climate. And even reconsider what the definition of a wall is. A summary of the main theories and methods from Science and Technologies Studies (STS), Design Engineering and Sustainability Science is reported in Table 2.

Table 2. Summary of the main theories $(T)$ and methods $(M)$ from Science and Technologies Studies (STS), design, design engineering and sustainability science used by Cara D'Anjo and Tolman (2019) to perform their analysis.

\begin{tabular}{|c|c|c|}
\hline Element & Theory(T)/Method(M) & Contribution \\
\hline STS & $\begin{array}{l}\text { Actor-Network } \\
\text { Theory }(\mathrm{T})\end{array}$ & $\begin{array}{l}\text { To map and analyse human \& non-human actors, controversies and } \\
\text { to assess the reconfiguration of responsibilities for new solutions. }\end{array}$ \\
\hline STS & $\begin{array}{c}\text { Multi-Level } \\
\text { Perspective }(\mathrm{T})\end{array}$ & $\begin{array}{l}\text { To conceptualize the transition value of solutions not only as part of } \\
\text { the current system but mainly as part of a transition to a sustainable } \\
\text { building system. }\end{array}$ \\
\hline Design & Desi & $\begin{array}{r}\text { To identify and determine different actors knowledges, preferences } \\
\text { and limitations in relation to the solution space. }\end{array}$ \\
\hline $\begin{array}{l}\text { Design } \\
\text { Engineering }\end{array}$ & $\begin{array}{l}\text { Material Driven } \\
\text { Design (M) }\end{array}$ & $\begin{array}{r}\text { To map and define the potentials and limitations in the selected } \\
\text { materials. }\end{array}$ \\
\hline $\begin{array}{l}\text { Design } \\
\text { Engineering }\end{array}$ & $\begin{array}{l}\text { Material Prototyping } \\
\text { and Testing }(\mathrm{M})\end{array}$ & $\begin{array}{r}\text { To produce working examples of new materials and testing them in } \\
\text { expected situations and systems. }\end{array}$ \\
\hline $\begin{array}{l}\text { Sustainability } \\
\text { Science }\end{array}$ & $\begin{array}{l}\text { Multi-level } \\
\text { Perspective (T) and } \\
\text { Systems } \\
\text { Reconfiguration (T) }\end{array}$ & $\begin{array}{l}\text { To frame the design task not as a conventional component } \\
\text { substitution, but as a component design to increase the potential of } \\
\text { supporting further a transition to sustainability in the building } \\
\text { industry. }\end{array}$ \\
\hline
\end{tabular}

Figure 4 shows schematically the argument. On the ground floor to the left are the current actors and materials for building. Proposing a new material without altering this context would be a substitution approach, represented by the elevator between the basement and the ground floor in which textile based insulation replaces current materials without altering the rest of the configuration. However the students propose a gradual approach in which textile insulation is coupled to hygroscopic wall design to allow for temperature insulation, without creating an air barrier. Put in another way, textile insulation with hygroscopic wall materials could allow for a design of walls can breathe, solving many issues of differentiated moisture levels between indoors and outdoors and unwanted water condensation indoors and even inside the insulation material or the buildings structure.

Designing the insulation does not deliver on all objectives, but having a sustainable transition approach to the problem encourages designers to think and outline what is the role a new component design could play in a desired transition in the building industry. Therefore, the scope is not to solve for a narrow technical frame, but to solve for an open long term systemic approach projecting how the proposed solution could enable future transformations of the building industry in sustainable directions. 


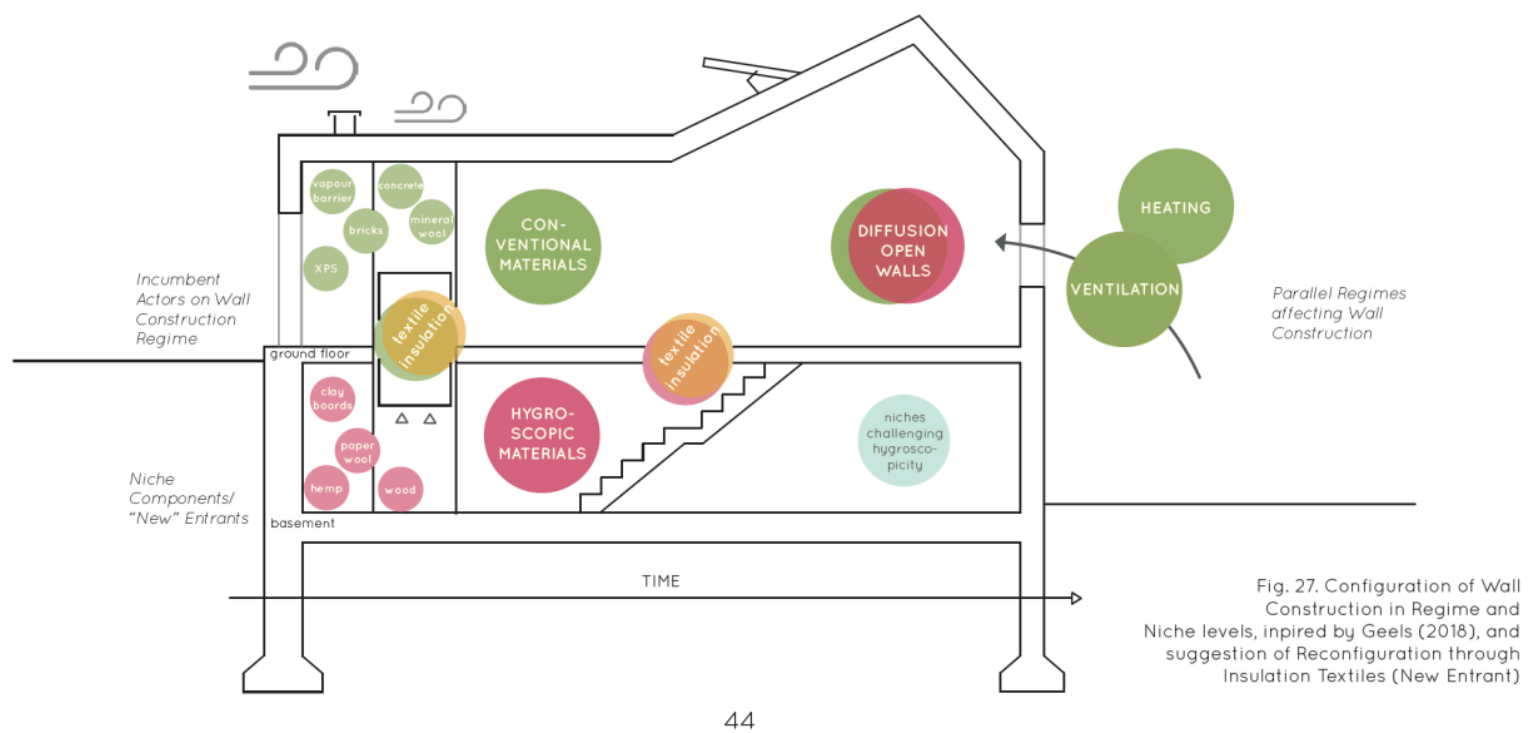

Figure 4. Representation of the current and suggested configuration of wall construction system (Cara D'Anjo and Tolman, 2019, p. 44)

Figure 5 shows that framing design in a sustainable transitions perspective requires opening up and considering the determinants of indoor climate -like ventilation- and considering the properties of the materials that constitute a wall. This in turn might also require further research into what makes an indoor climate healthy and characterizing what is it that makes current indoor climate technologies unhealthy and unsustainable.
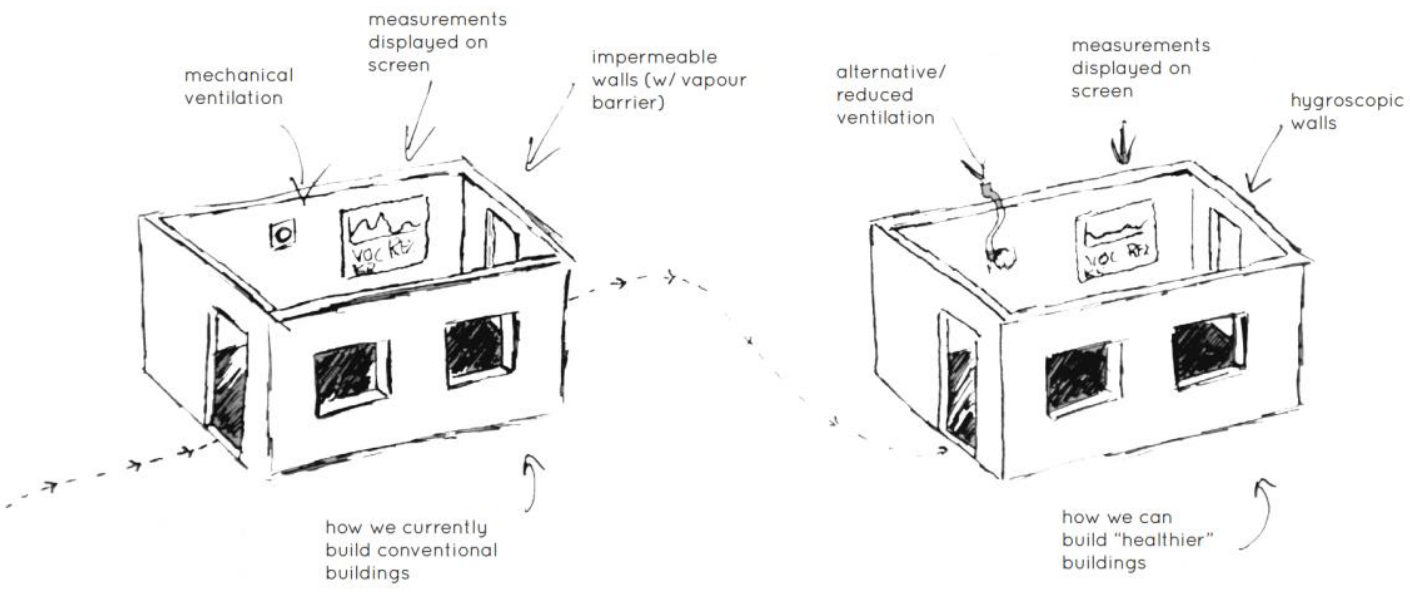

62

Figure 5. Representation of the current conventional building (on the left) and a concept for how "healthier" building (on the right) (Cara D'Anjo and Tolman, 2019, p. 62)

As a conclusion we could claim that the students build on Smith and Raven (2012) conceptualized contrast between innovations that adopt a fit and conform approach vs those that attempt a stretch and transform one. Fit and conform innovations attempt at substituting a component of an existing system with a sustainable one without expecting the whole system to change. The transformative potential of this approach is therefore limited, although it might be quite safe in terms of not upsetting current dominant actors and structures. However, the students propose that new building components should be designed in a way in which they both can deliver on the function within the existing system and facilitate future stretch and transform strategies. Put it in other words, the component should be designed in a way in which it can also perform in a systemic transformation and even support it. 


\subsection{Food sector}

The second example deals with the food sector and refers to the report developed by three students (Rodriguez Pariza et al., 2019). In their thesis they aimed to understand the creation of conscious consumer practices in the Danish canteen context and introduced a 'design thing' to facilitate a dialogue among consumers and canteen staff to realise steps towards more local food consumption as example issue for sustainably conscious consumption.

According to the AAU-PBL model they investigated the research field and found that information on environmental impact and origin of food can be an important factor in bringing back the connection between food production and the consumer. Transparent communication on food processes from the suppliers and food producers towards the consumer is needed and this information might lead to the creation of awareness on the environmental impact of consumption and therefore, encourage consumers to choose or evaluate food with a less environmental impact. They adopted a reductionist perspective, narrowing to studies of consumption, behaviour and food provisioning, to deal with the complexity that the food system entails. The context of the research was Denmark's capital Copenhagen, being one of the leading gastronomic destinations in the world, with a particular focus on the public catering sector which can affect the choices of consumers (Goggins and Rau, 2016).

Based on the analysis of the state of the art, they formulated two RQs: i) How can information on the origin of the food trigger a dialogue between consumers on local food consumption? and ii) How can we create new opportunities towards more sustainably conscious practices in Danish canteens?

First, they studied the main issues around food consumption and gained an overview of its complexity. Many previous studies agreed that local food consumption would support the local economy and create a social reconnection between producer and consumer and for certain products reduces environmental impact. The European Union and the United Nations also demand food organisations to be transparent with information about food for consumers to make more conscious choices, especially the EU with new regulation demanding to explicitly point out the origin of main ingredients of products (EC, 2011).

Second, they created an overview of the practice of 'lunching at the canteen' by means of 5 semi-structured interviews with relevant catering professionals, observations and questionnaires distributed in three canteens. This investigation provided an understanding of the multiple viewpoints and opportunities for change in a restricted context of a Danish canteen. They used Practice Theory to know what influences people's choices in canteens and Actor-Network Theory (ANT) to map the interconnections of the different actors in the system to facilitate the negotiations among them. A few interviews are accepted as valid empirical material as long as they comply with the principle of saturation (Yin, 2016).

Third, they initiated a design process, through the development of an iterative design object (named "design thing"), which was used as a means for sharing knowledge in the network. This object used information on the origin of food as main subject for a dialogue on the concerns of locality between consumers and client in the context of one representative canteen. The quantification of the potential environmental impacts on the climate change (carbon footprint) during the production stage was used to exemplify the environmental impacts of different ingredients.

Table 3 summarizes the theories and methods from the Design Engineering and Sustainability Science research fields used in the study and their contribution to answer the research questions.

Table 3. Summary of the main theories $(T)$ and methods $(M)$ from Design, Design Engineering and Science and Technology Studies (STS) used by Rodriguez Pariza et al. (2019) to perform their analysis.

\begin{tabular}{|l|c|l|}
\hline Element & Theory/Method & \multicolumn{1}{|c|}{ Contribution } \\
\hline Design & $\begin{array}{c}\text { Design game } \\
(\mathrm{M})\end{array}$ & A means for sharing knowledge in the network \\
\hline STS & $\begin{array}{c}\text { Practice } \\
\text { Theory (T) }\end{array}$ & $\begin{array}{l}\text { To know what influences people's choices in canteens and knowing the } \\
\text { context where they could act }\end{array}$ \\
\hline STS & $\begin{array}{c}\text { Actor Network } \\
\text { Theory (T) }\end{array}$ & $\begin{array}{l}\text { To map the interconnections of the different actors in the system to } \\
\text { facilitate the negotiations among them }\end{array}$ \\
\hline $\begin{array}{l}\text { Design } \\
\text { Engineering }\end{array}$ & $\begin{array}{c}\text { Carbon } \\
\text { Footprint }(\mathrm{M})\end{array}$ & $\begin{array}{l}\text { To quantify the potential environmental impacts on climate change of the } \\
\text { production stage of different ingredients }\end{array}$ \\
\hline
\end{tabular}


In total 11 sessions of design game workshop were conducted and facilitated by the three students. In each session, individuals or groups of 2 or 3 participants, were invited. The workshop took place during the lunchtime, thus allowing consumers to have a scenario where they could reflect on the impact of their experience while performing the regular practice, lunching (Scott et al., 2012). The design game was developed step-by-step over multiple phases. Each session started with presentation of information on the mechanism of the game, with explanation of rules and restrictions in order to create a meaningful new recipe. Once the participants were familiar with the design game and how to create a recipe, they were then introduced to environmental impacts of each ingredient. A template was then provided to the canteen staff and pictures of the final recipe. Participants could write down their (group) name, the name of the recipe and the qualities of the recipe in whatever way the deemed fit on the recipe template. In the same way, discussions around personal preferences, concerns and values were encouraged and concluded during the same phases and manner.

The main contribution of this project is also both practical and conceptual. The construction of the "design thing: create a Recipe", shown in Figure 6, allowed to establish a dialogue and interaction with consumers on what they like to eat at the canteen and the related environmental concerns of their lunches. The creation of a bottom-up approach was successful, focusing on the engagement of key actors that can push the market or make the practical changes, such as consumers and the canteen staff.

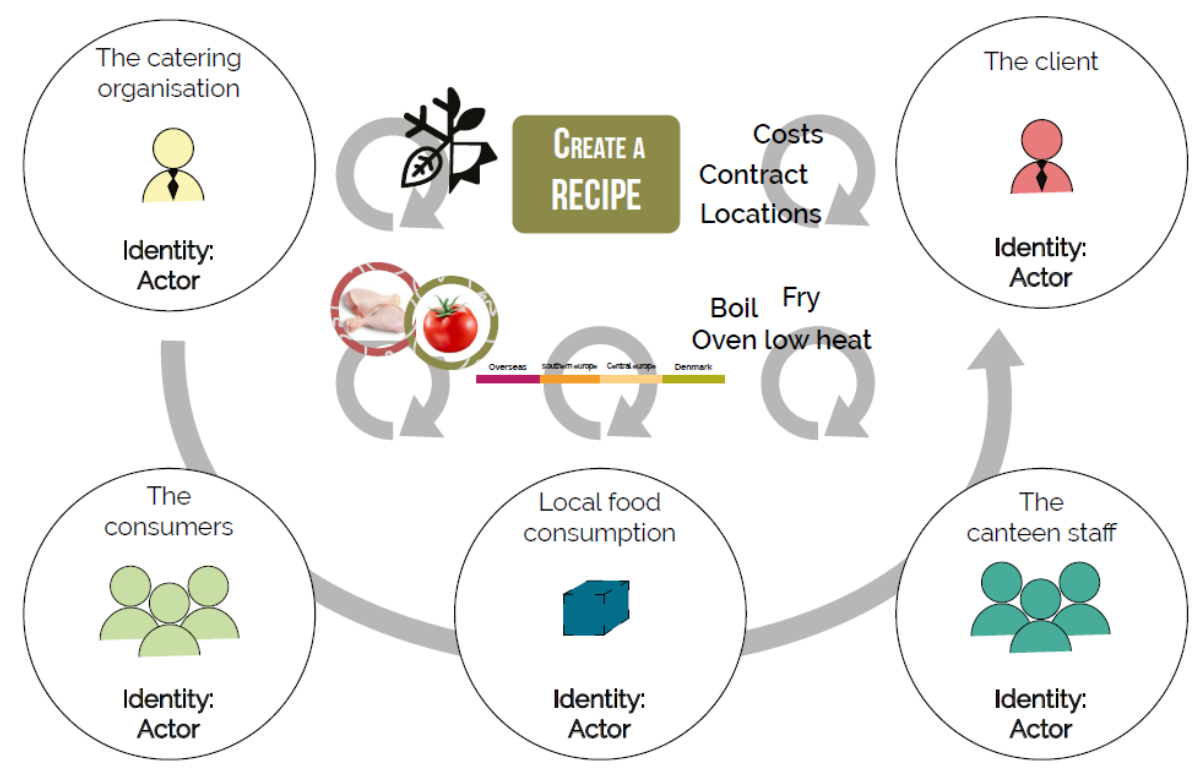

Figure 6. Representation of the design thing: create a recipe (Rodriguez Pariza et al., 2019, p. 35)

\section{Conclusions}

Sustainable Design Engineering (SDE) is an emerging research field which builds on knowledge from other research fields with their own traditions: Sustainability, Design and Design Engineering under the umbrella of Science and Technologies Studies. University programmes need to be open to experiment unconventional ways of teaching that are able to provide knowledge, skills and competences both on a practical and theoretical level. The AAU-PBL model allows for such flexibility and the SDE programme at AAU-CPH is an example of how design engineers can combine knowledge from different disciplines and sectors, such as the building and textile sectors (Cara D'Anjo and Tolman, 2019) and among different actors, such as consumers and canteen staff (Rodriguez Pariza et al., 2019).

\section{Acknowledgement}

We would like to thank all the students of the SDE program at AAU Copenhagen who graduated in July 2019, for the inspiring discussions and for their contribution in shaping the field of Sustainable Design Engineering. 


\section{References}

Askehave, I. et al. (2015), PBL. Problem Based Learning. [online] Aalborg Universitet Rektorsekretariatet. Available at: http://www.aau.dk/digitalAssets/148/148025_pbl-aalborg-model_uk.pdf (accessed 30.10.2019).

Brundtland, G.H. et al. (1987), Our common future, New York.

Cara D'Anjo, M. and Tolman, T. (2019), Calling the world from insulation: re-configuration of sociotechnical systems through product development, [Master Thesis], Aalborg University.

Ceschin, F. and Gaziulusoy, I. (2016), "Evolution of design for sustainability: From product design to design for system innovations and transitions", Design Studies, Vol. 47, pp. 118-163. https://doi.org/10.1016/ j.destud.2016.09.002

Clausen, C. and Yoshinaka, Y. (2007), "Staging socio-technical spaces: translating across boundaries in design", Journal of Design Research, Vol. 6 No. 1-2, pp. 61-78. https://doi.org/10.1504/JDR.2007.015563

Dym, C.L. et al. (2005), "Engineering design thinking, teaching, and learning", Journal of Engineering Education, Vol. 94 No. 1, pp. 103-120. https://doi.org/10.1002/j.2168-9830.2005.tb00832.x

EC. (2011), Regulation (EU) No 1169/2011 of the European Parliament and of the Council on the provision of food information to consumers. European Commission, Brussels.

EC. (2015), COM (2015) 614 Communication from the Commission to the European Parliament, the Council, the European Economic and Social Committee and the Committee of the Regions. Closing the loop - An EU action plan for the Circular Economy. European Commission, Brussels.

Goggins, G. and Rau, H. (2016), "Beyond calorie counting: Assessing the sustainability of food provided for public consumption", Journal of Cleaner Production, Vol. 112, pp. 257-266. https://doi.org/10.1016/j. jclepro.2015.06.035

Kolmos, A. et al. (2008), Facilitation in a PBL environment, UCPBL UNESCO Chair in Problem Based Learning, Aalborg.

Kuhlman, T. and Farrington, J. (2010), "What is sustainability?”, Sustainability, Vol. 2 No. 11, pp. 3436-3448. https://doi.org/10.3390/su2113436

Leach, M., Raworth, K. and Rockström, J. (2013), "Between social and planetary boundaries: navigating pathways in the safe and just space for humanity", UNESCO/ISSC. https://doi.org/10.1787/978926420341910-en

Mulder, K.F. (2019), “Is Progress to Sustainability Committed Engineers Stalking?”, Journal of Modern Education Review, Vol. 9 No. 1, pp. 23-28. https://dx.doi.org/10.15341/jmer(2155-7993)/01.09.2019/003

Pineda, A.F.V. and Jørgensen, U. (2018), "The challenges of teaching sustainable System Design" In DS 92: Proceedings of the DESIGN 2018/15th International Design Conference Dubrovnik, Croatia, May 21-24, 2018, The Design Society, Glasgow, pp. 2485-2494, https://doi.org/10.21278/idc.2018.0528

Randers, J. et al. (2018), Transformation is feasible: How to achieve the Sustainable Development Goals within Planetary Boundaries. A report to the Club of Rome from Stockholm Resilience Centre and BI Norwegian Business School.

Rockström, J. et al. (2009), "Planetary boundaries: exploring the safe operating space for humanity", Ecology and society.

Rodriguez Pariza, I., Ageitos Lantigua, L.J. and Höfte, M.H.B. (2019), The long road to consciuos consumption practices: The origin of food as key to raise awareness for sustainable local food in the Danish canteen. [Master Thesis]. Aalborg University.

Saxe, H., Larsen, T. and Mogensen, L. (2013), "The global warming potential of two healthy Nordic diets compared with the average Danish diet", Climatic Change, Vol. 116 No. 2, pp. 249-262. https://doi.org/10. 1007/s10584-012-0495-4

Smith, A. and Raven, R. (2012), "What is protective space? Reconsidering niches in transitions to sustainability", Research Policy, Vol. 41 No. 6, pp. 1025-1036. https://https://doi.org/10.1016/j.respol.2011.12.012

Savin-Badin, M. (2014), "Using problem-based learning: New constellations for the 21st century", Journal on Excellence in College Teaching, Vol. 25 No. 3\&4, pp. 197-219.

Scott, K., Bakker, C. and Quist, J. (2012), "Designing change by living change", Design Studies, Vol. 33 No. 3 , pp. 279-297. https://dx.doi.org/10.1016/j.destud.2011.08.002

Storni, C. (2015), "Notes on ANT for designers: ontological, methodological and epistemological turn in collaborative design", CoDesign, Vol. 11 No. 3-4, pp. 166-178. https://doi.org/10.1080/15710882. 2015.1081242

Yin, R.K. (2017), Case study research and applications: Design and methods, Sage publications. 